\title{
A CONSTRUÇÃO DA AUTOESTIMA E AFIRMAÇÃO DAS IDENTIDADES NEGRAS NAS CRIANÇAS QUILOMBOLA
}

\author{
José Artur do Nascimento Silva ${ }^{1}$ \\ Julvan Moreira de Oliveira ${ }^{2}$
}

\begin{abstract}
RESUMO: Ao realizarmos contato com uma escola localizada em uma tradicional comunidade quilombola, na região de União dos Palmares - $\mathrm{AL}$, e ouvirmos as narrativas das crianças com um imaginário que desvalorizava a identidade negra, objetivamos conhecer por meio de pesquisa bibliográfica especificamente sobre as relações étnico-raciais, que pudesse dar um suporte teórico necessário para se conhecer e compreender as atuais discussões sobre o racismo, o preconceito e a discriminação racial, sobretudo no campo educacional. Este estudo não identificou trabalhos delimitados sobre a construção da identidade étnico-racial no universo da educação quilombola. Conclui-se que as narrativas apresentadas pelas crianças em nosso contato com a comunidade quilombola Muquém necessitam ter a oportunidade de construir relacionamentos saudáveis consigo mesmas e com seus pares e que estejam fundamentadas com a valorização da identidade quilombola.
\end{abstract}

Palavras-chave: Quilombo dos Palmares. Muquém. Crianças. Negras. Identidade étnico-racial.

\section{THE CONSTRUCTION OF SELF-ESTEEM AND AFFIRMATION OF BLACK IDENTITIES IN QUILOMBOLA CHILDREN}

ABSTRACT: Through the contact with a school in a traditional quilombola region (Palmares, AL, Brazil), and through the kids narratives that showed a devalued imagination of their black identity, we've made a bibliographic research,

\footnotetext{
${ }^{1}$ Doutorando em Educação pela Universidade Federal de Juiz de Fora (UFJF); Mestre em Educação pela Universidade Federal de Alagoas (UFAL); Professor da Rede Municipal de Ensino de União dos Palmares, Al. E-mail: artus2007nascimento@hotmail.com

${ }^{2}$ Professor do Programa de Pós-graduação em Educação e do Programa de Pós-graduação em Gestão e Avaliação da Educação Pública da Universidade Federal de Juiz de Fora; Doutor e mestre em Educação pela USP; Licenciado em Filosofia pela USF; Líder do Grupo de Estudos e Pesquisas ANIME (Africanidades, Imaginário e Educação). E-mail: julvan.moreira@ufjf.edu.br
} 
specifically about the ethnical and racial subjects, that gave us the theoretical support needed to get to know and comprehend the current racism, prejudice and racial discrimination debates, especially in the educational field. This study identified that there is no research specifically about the formation of ethnicalracial identity in the quilombola educational field. We could conclude that Muquém quilombola need to have the opportunity to build healthy relationships with themselves and with their peers and that be based on the valorization of quilombola identity.

Keywords: Quilombo dos Palmares. Muquém. Children. Black people. Racialethnical Identity.

\section{LA CONSTRUCCIÓN DE LA AUTOESTIMA Y LA AFIRMACIÓN DE LAS IDENTIDADES NEGRAS EN LOS NIÑOS QUILOMBOLAS}

RESUMEN: Al contactar una escuela ubicada en un quilombo tradicional, en la región de Palmares - AL - Brasil, y oír las narrativas de los niños con un imaginario que desvalorizaba la identidad negra, objetivamos realizar una investigación bibliográfica, específicamente sobre las relaciones étnico-raciales, que podrían proporcionar el apoyo teórico necesario para conocer y comprender las actuales discusiones sobre el racismo, el preconcepto, la discriminación racial, especialmente en el campo educacional. En este estudio no se identificó trabajos específicos sobre la construcción de la identidad étnico-racial en el universo de la educación quilombola. Se concluye que las narrativas presentadas por los niños en nuestro contacto con la comunidad quilombola de Muquém necesitan tener la oportunidad de construir relaciones saludables con ellos mismos y con sus compañeros y que se basen en la apreciación de la identidad quilombola.

Palabras clave: Quilombo dos Palmares. Muquém. Niños. Negras. Identidad étnico-racial.

\section{Introdução}

É agosto de dois mil e dezessete, nas proximidades da semana do folclore brasileiro, e eis que na escola da Comunidade de Remanesceste Quilombola de Muquém, em União dos Palmares - AL, localizada aos pés da Serra da Barriga, saem 
para o horário de intervalo quatro crianças, param diante de um cartaz que fazia alusão ao folclore e iniciam o seguinte diálogo:

- Dandara: Eu sou essa... (e leva o dedo até a lara, uma personagem do folclore brasileiro, representada geralmente pelo tom de pele branca, cabelos loiros, lisos, olhos claros...).

- Tereza: Ah! Eu também sou essa daqui... (e leva o dedo até a lara).

- Pedro: Ah! Eu sou esse daqui... (e leva o dedo até o boto cor de rosa, um homem branco, cabelos lisos...).

Observado esse diálogo, cabe-nos ressaltar que todas as crianças citadas acima eram, aos nossos olhos, visivelmente negras, mas não se identificaram nesse momento observado e nos perguntamos se esta razão se daria em decorrência de não haver no cartaz personagens negros, para que elas pudessem, inclusive, apontar para os mesmos. Diante dessa assertiva, várias reflexões nos vieram à tona, de modo que indagamos: o que levaria essas crianças e negras a se perceberem nesses personagens do folclore brasileiro? O que as levaria a não percepção desse não reconhecimento? Como no currículo de uma educação escolar quilombola seria possível visualizar esse cenário eurocêntrico, patriarcal, branco e a figura do negro inviabilizada? O currículo dessa escola desprezava as práticas pautadas por um currículo pós-crítico ou faltavam, apenas aos nossos olhos, possibilidades de representatividades?

De antemão, gostaríamos de salientar, que estamos longe de pregar qualquer julgamento mediante qualquer prática escolar, entretanto, disponibilizamos nossos olhares para enxergamos outras possibilidades diante do fato narrado, que foi fruto de uma observação participante, de quando realizou-se a pesquisa para coletar os dados para análise da dissertação de mestrado. Ela não possuía vínculo direto com as crianças e negras e sim com práticas curriculares em escolas quilombolas, mas que culminaram na possibilidade desta escrita, e futura, sobre o processo de construção da identidade 
étnico-racial das crianças e negras quilombolas.

O texto que aqui segue não é fruto apenas dessa observação, mas também de várias análises do nosso cotidiano, nos espaços que frequentamos enquanto crianças e negras que fomos e a partir da percepção de como outras são tratadas, especificamente, dentro do ambiente escolar, mas neste caso, reportaremos nossos horizontes, para as crianças e negras quilombolas. Nesse sentido, pensar a criança e negra historicamente em um país tipicamente racista, como o nosso Brasil, está longe de imaginá-la como protagonista dos cenários educacionais que elas ocupam.

Nessa perspectiva, Silva (2011) percebeu o quanto crianças de pele clara têm discriminado crianças e negras e algumas delas não reagem ao ato, outras ficam envergonhadas, outras agridem, e ainda há professores que acham ser brincadeiras de crianças. Essa marca da agressão, do silenciamento, da negação do outro, da inferiorização, do preconceito materializado na discriminação racial tem tentando negar a existência também do povo negro por longas datas.

Nesse cenário histórico temos percebido as tensas relações entre brancos e negros ao longo da história nada harmoniosa, como pregava Freyre (2006), a despeito de uma falsa harmonização entre as raças e que o Brasil era um país harmônico. Se pensarmos os diferentes contextos e cenários em que essa falsa harmonização foi estabelecida, é possível perceber o quão cruel, desumana e desvalorizativa era, pois desconsiderava a existência do racismo, da discriminação, da condição desumana, da subalternidade, da falta de escolarização, dos serviços de escravização que homens e mulheres eram obrigados a servir aos "senhores da época".

O trabalho de escravização do período colonial tem tomado outra conjuntura, outra dimensão, atualmente, e com ele temos percebido o quanto o quesito raça-cor tem lugar predominante - nas zonas periféricas, favelas, bairros afastados dos grandes centros. É como se ocupássemos sempre esses mesmos espaços e consequentemente 
lugar. Conforme Schwarcz (2012), raça nunca foi um termo neutro, ao contrário, ora era vista como positiva, mas na maior parte do tempo, negativa, o que é possível observar no quanto homens, mulheres, crianças e negras ocupam papéis inferiores e negativos na sociedade brasileira.

Um, entre os vários espaços que as crianças negras ocupam é o ambiente escolar. Nele, constantemente, elas são alvo de piadas racistas e discriminatórias. Sobretudo, não cogitamos a possibilidade de estarmos longe de encontrarmos em nossos espaços formais de educação, situações relatadas por Guimarães (1998, p. 10), "Mãe, se chover água de Deus, será que sai a minha tinta? - Credo-em-cruz! Tinta de gente não sai. Se saísse, mas se saísse mesmo, sabe o que ia acontecer? - Pegou-me e, fazendo cócegas na barriga, foi dizendo: - você ficava branca e eu preta [...]". Mas, se encontrarmos, certamente precisamos dialogar com os diversos segmentos do ambiente escolar para propormos um trabalho de fortalecimento, reconhecimento e valorização do povo negro. Porém essa negação, desejo de ter outra cor de pele, justifica-se aos apelidos e termos pejorativos que a nós, quando crianças, nos foram dados: carvão, tição, negrinho, macaco e tanto outros (SILVA, 2004).

É importante pontuarmos para a necessidade de se realizarem trabalhos que respeitem, valorizem, contribuam para o fortalecimento da identidade étnica das crianças e negras nos espaços escolares. Para isso, necessitamos fortalecer, repensar as formações continuadas recebidas pelos professores e como isto tem refletido nas práticas com as crianças. É sabido por todos que os programas didáticos, os currículos escolares dão supremacia a uma raça em detrimento da outra, mas é preciso desconstruir essa supremacia e uma via está na inserção da $10.639 / 03^{3}$ e da

\footnotetext{
${ }^{3}$ A lei 10.639/03 alterou a Lei de Diretrizes e Bases da Educação Nacional (LDB), de n. 9.394/96, incluindo a obrigatoriedade do ensino de História e Cultura Africana e Afro-brasileira na Educação Básica.
} 
11.645/08 ${ }^{4}$, que mesmo sendo leis, ainda carecem de um estudo aprofundado das questões trazidas por elas.

Consideramos necessário o rompimento com práticas que não dão visibilidades às relações étnicas das crianças e negras dentro dos espaços escolares em comunidades quilombolas. E apontar um caminho que atravesse essa ruptura se pauta em como a educação para as relações étnico-raciais pode contribuir significativamente para a construção positiva das identidades étnicas das crianças e negras. Para além, o diálogo ultrapassa a lógica de uma criança única, universal, e, em parte direciona o olhar para a diversidade, impessoalidade, da pluralidade (ABROMOWICZ, 2010). Entretanto, esse debate deve interessar à educação e aos sujeitos envolvidos nesse processo, independente da forma como se autodeclaram em relação as suas identidades étnicas, tendo em vista as mudanças ocorridas na política educacional brasileira nos últimos anos, como as implementações das Leis 10.639/03 e 11.645/08, bem como as Diretrizes Curriculares Nacionais para Educação das Relações Étnicoraciais e Ensino de História e Cultura Afro-brasileira, Indígena e Africana, além das Diretrizes Curriculares Nacionais para a Educação Escolar Quilombola (2012).

Na primeira parte deste artigo nós apresentaremos aos leitores o Quilombo dos Palmares, o maior símbolo de resistência da população negra, suas figuras emblemáticas, seus costumes, modos de sobrevivência, a resistência como sinônimo de luta, seu surgimento, como ocorria o processo de escolha dos líderes, suas maiores lideranças. Apontamos também as principais mulheres que lutaram pela liberdade do seu povo e de como chegamos até a comunidade de remanescentes de quilombolas Muquém.

Em seguida, propusemos um diálogo inicial acerca do processo de construção

\footnotetext{
${ }^{4}$ A lei $11.645 / 08$ alterou a lei 10.639 , incluindo Indígenas. 
das identidades étnico-raciais das crianças e negras quilombolas de Muquém, a partir de dois momentos: um, diante de uma cena presenciada no período de observação para a pesquisa de mestrado, que não se relacionava diretamente com o objeto pesquisado, mas com a temática aqui proposta; outro, a partir de um relato de uma situação vivenciada em momento de uma atividade extraescolar, fora do ambiente escolar, mas de grande reflexão para o debate em torno da raça, preconceito, discriminação racial e racismo. Por fim, traremos algumas inconclusões acerca de um trabalho inacabado, porém reflexivo e combativo na luta pela igualdade do direito de sermos quem somos: negros, não negros, quilombolas, crianças.

\section{Atravessamentos possíveis: o Quilombo dos Palmares, a Comunidade Quilombola de Muquém e os espaços existentes "não formais de educação"}

A resistência do negro à escravidão foi característica marcante da história dos africanos nas colônias americanas, e os escravizados (adendo nosso) responderam à exploração com a má vontade, a sabotagem ao trabalho a revolta ou a fuga para quilombos. (FUNARI, 2012, p. 31).

\section{O Quilombo dos Palmares: a travessia para Muquém}

O Quilombo dos Palmares, localizado na Serra da Barriga, no município de União dos Palmares, Estado de Alagoas, é o maior símbolo da América Latina contra o período de escravização existente no país. Tem como figuras emblemáticas, para além de Zumbi dos Palmares, herói negro que lutou junto a Gaga Zumba contra a escravização, líderes da República. Devemos evidenciar também três mulheres e negras que estiveram além do tempo e chefiaram, cada uma delas, um, entre os dozes Mocambos que existiam na região de Palmares - Dandara, Acotirene e Aqualtune -que são 
símbolos de resistência e luta pela liberdade das mulheres e do povo negro.

Das rotas de fugas citadas por Funari (2012), destaca-se, entre outros quilombos, o de Palmares, maior reduto de ex-escravizados fugitivos das casas grandes e senzalas, que lutavam contra todo sistema de opressão, escravização a que eram forçadamente submetidos. Palmares ganhou este nome em decorrência do alto número de palmeiras que existia no seu entorno. É símbolo, até os dias atuais, de luta, resistência, reverência, combate contra a dominação e opressão.

Palmares foi uma república, "cujo sentido nada tem a ver, portanto, com a ideia de "regime republicano", por ocasião da monarquia, e Palmares nunca foi uma república neste sentido" (FUNARI, 2012, p. 31); mas, no de assegurar a defesa e a sobrevivência contra o colonialismo escravista (FIABANI, 2012). O lugar era de difícil acesso, de matas fechadas, matos espinhosos, cipós e arbustos, com montanhas e pequenos morros a sua volta, havia vários mocambos ao redor de Palmares, dentre eles, o de Cerca Real dos Macacos, que originou posteriormente, o primeiro nome da cidade de União dos Palmares.

A partir deste contexto, Palmares

se iniciou antes de 1630: [...] e por aqueles sítios se refugiaram, das fazendas vizinhas, os negros que se escapavam aos rigores dos cativeiros. [...] estado negro que nos recessos das brenhas assim se constituíra e fortalecera, tinha tido começos mais modestos em diminuta reunião de escravizados fugidos, que iam aumentando de número com o tempo (FIABANI, 2012, p. 56).

Entre esses diferentes grupos da sociedade brasileira, estavam os homens e mulheres negras/os que não estavam dispostos a se submeter aos caprichos, castigos, humilhações dos que se intitulavam seus "senhores" e buscaram formar os quilombos com "escravos libertos e insurretos e negros livres antes e depois da abolição. Enquanto vigora a escravidão, os quilombos cumprem função de abrigar as populações negras, configurando um tipo de resistência" (FIABANI, 2012, p. 29). 
Palmares estava organizado para combater os inimigos. Apesar de ter sofrido vários ataques, seus habitantes ganhavam a cada batalha mais força, por meio de estratégias para enfrentá-los, além de alto nível de produção de armas artesanais, bem como o mapeamento de pontos estratégicos dentro das matas que havia no entorno da Serra da Barriga, o que facilitava os contra-ataques a quem pensasse tentar destruir Palmares.

Palmares não estava limitado ao platô da Serra da Barriga. No seu entorno havia mocambos que eram chefiados por homens e mulheres que os lideravam. Entretanto, eles não viviam em um sistema de subordinação, em que o/a chefe/a era o superior, tomavam as decisões a sós, e que posteriormente o grupo era comunicado. Em Palmares, ocorria o processo contrário:

os documentos revelam que todos os moradores reunidos em assembleia escolhem os membros de um conselho. Este, por sua vez, elege um chefe, cujos poderes, apesar de amplos, não dispensam a consulta popular quando estão em jogo decisões cruciais para a vida quilombola (GENNARI, 2011, p. 38).

O maior líder de Palmares foi Zumbi, que quando ainda criança foi parar nas mãos do padre Antônio Melo que Ihe batizou, deu-Ihe o nome de Francisco. Nasceu livre em 1655, sobrinho de Ganga-zumba. Zumbi aprendeu várias línguas na convivência e criação do padre, entre elas o latim. "Seu nome refere-se a seu provável papel espiritual na comunidade, zumbi sendo associado com um título banto, religioso e militar a um só tempo" (FUNARI, 2012, p. 36). Aos quinze anos de idade, resolveu fugir para o Quilombo de Palmares. “Aos vinte e dois, ele comanda parte das milícias palmarinas contra as investidas das tropas de Fernão Carrilho, ocasião na qual a direção geral das operações militares está nas mãos de Ganga-zumba" (GENNARI, 2011, p. 50).

Para sobreviver em Palmares, os palmarinos, como eram chamados os 
habitantes dos vários mocambos, caçavam, pescavam, plantavam, colhiam frutas e raízes da região. Com o passar do tempo, "criam instrumentos de madeiras para lavrar a terra e, após encontrar minério de ferro em seu território, começam a forjar armas de corte e ferramentas para o trabalho agrícola" (GENNARI, 2011, p. 36). Como a terra era produtiva, devido ao solo ser fértil, tudo que se plantavam, colhiam: feijão, mandioca, milho, batata, legumes, cana-de-açúcar, árvores com diversos tipos de frutas e sabores, além de alguns animais como porco, cabra, bode, galinha entre outros. Portanto, "[...] a indústria artesanal raramente se separava da agricultura [...]" (FIABANI. 2012, p. 158).

Ressalva-se que o povo negro, branco, índio e pardo que viveu em Palmares foi acima de tudo um povo que não escolheu o lado fácil da história, da sobrevivência e resolveu lutar e resistir unido. As batalhas travadas, durante o período de escravização dessa nossa gente, foram as maiores formas de lutar e resistir contra o opressor, contra uma política de escravização que desumanizava, inferiorizava, tentava colocar o outro em lugar subalterno. A luta foi pela liberdade. Foi contra o racismo impregnado nos capitães do mato, nos senhores e senhoras de engenho. Mas ainda há um povo, uma gente que luta pelo legado deixado pelos nossos ancestrais. Os povos das comunidades de remanescentes quilombolas, espalhadas pelos diversos cantos do país e, entre elas, está Muquém. Resistimos!

\section{A Comunidade Remanescente Quilombola de Muquém: os vestígios de Palmares}

As comunidades de remanescentes quilombolas no Brasil têm ganhado outras dimensões a partir de sua constituição, enquanto lugares de "negros fujões", "Iugar de preto", "lugar de escravizados", "espaços rurais" e tomado outra conjuntura, posterior, não só à derrubada dos quilombos que resistiram ao período escravocrata, mas 
também a partir das várias possibilidades de nos criarmos em diferentes espaços, outros espaços que simbolizem as lutas dos que lutaram, cada um em sua região, pela liberdade do seu povo. No processo de escravização, quilombos, eram considerados comunidades organizadas por africanos livres que se recusaram a submeterse aos grilhões e à chibata. Africanos orgulhosos de sua liberdade e dignidade humana. Os quilombos, que variavam segundo o tamanho das terras ocupadas e o número de seus habitantes, via de regra mantinham bem organizada e eficiente produção agrícola, formas de vida social instituídas segundo modelos tradicionais africanos adaptados à nova realidade da América (NASCIMENTO, 1980, p. 37).

E a partir dessa contextualização Schimdt, Turatti e Carvalho, (2002, p. 3), afirmam que as comunidades de remanescentes quilombolas, se constituíram a partir de

\begin{abstract}
uma grande diversidade de processos, que incluem as fugas com ocupação de terras livres e geralmente isoladas, mas também as heranças, doações, recebimento de terras como pagamento de serviços prestados ao Estado, a simples permanência nas terras que ocupavam e cultivavam no interior das grandes propriedades, bem como a compra de terras, tanto durante a vigência do sistema escravocrata quanto após a sua extinção.
\end{abstract}

A partir do que está posto pelo autor, ressalta-se que Muquém surgiu de uma doação. Inicialmente, de acordo com seu Edson (2018), morador da comunidade, pertenceu ao casal

Rosa Maria dos Santos e Venâncio Bezerra da Silva, que se desfez de Muquém e ofereceu para o caseiro Miguel Bezerra da Silva que tomava conta das terras do casal. Miguel, para pagar as terras, pegou um empréstimo a Basiliano Sarmento para arrendar Muquém. Só que Miguel não conseguiu pagar a dívida e Basiliano Sarmento tomou as terras novamente e as colocou a leilão. A partir desse momento um homem bondoso, generoso comprou e deu para Casemiro Bezerra da Silva e Felícia Maria da Conceição para que quem estivesse em Muquém não saísse mundo afora (SEU EDSON, RELATO CEDIDO EM 2018). 
Certamente, Muquém surgiu após o período de derrubada de Palmares, e conta-se que os que conseguiram fugir se refugiaram no campo vasto que era Muquém, antes mesmo de ser habitado pelos seus fundadores, mas não contam ao certo seu destino. Posteriormente, ao ser habitado, os sujeitos, por estarem em terras que eram de remanescentes quilombolas, assim passaram a ser chamados.

no Brasil, começa pela definição de uma identidade quilombola a um grupo de negros africanos inseridos em uma sociedade de classes contraditória dentro do sistema capitalista agrário de fuga-resistência, ou seja, constituem formações sociais no interior do sistema capitalista agrário (SANTOS; ANJOS; FARIA, 2017, p. 157).

Entretanto, Muquém, hoje possui outro aspecto sócio habitacional. Suas casas antigas - algumas de taipa e barro, outras de alvenaria - deram lugar a outra estrutura 5 . Ganhou um centro ecumênico; um galpão para poder guardar suas peças e esculturas; um salão para apresentações e recepções dos visitantes; uma escola com amplas salas de aula, pátio, laboratórios e outras dependências. Mas, seu povo, sua gente, são os mesmos.

A partir dessa nova conjuntura, dimensão política, social e econômica em que o povo de Muquém passou a viver, tornou-se necessário entendermos que ele passou a ter uma visão contemporânea de quilombo, que se entende como

uma força social relevante no meio brasileiro, dando uma nova tradução àquilo que era conhecido como comunidades negras rurais (mais ao Centro, Sul e Sudeste do país) e terra de preto (mais ao Norte e Nordeste), que também começa a penetrar no meio urbano, dando nova tradução a um leque variado de situações que vão desde antigas comunidades negras rurais atingidas pela expansão dos perímetros urbanos até bairros no entorno de terreiros de candomblé (ARRUTI, 2005, p. 26).

\footnotetext{
${ }^{5}$ Após a enchente ocorrida no ano de 2010, as casas foram devastadas e substituídas pelas do Programa da Reconstrução do Governo Federal, no mesmo ano, porém só ficaram prontas um ano depois.
} 
Muquém não está longe do que afirma o autor, pois, além de ser localizada em espaço rural, ela fica próxima ao pé da Serra da Barriga. Muquém carrega marca de sua ancestralidade nos sujeitos que moram nela. Eles carregam consigo o registro do artesanato com argila, quer seja na construção de panelas, tachos, esculturas, quer seja nas apresentações e oficinas de danças afro-brasileiras, de capoeira, demarcados como patrimônio da herança cultural deixada pelos seus ancestrais.

Essas marcas, que definem os povos quilombolas, dentro de uma perspectiva contemporânea, têm aos olhos de Cunha Junior (2012, p. 163) implicações em diversas áreas, de modo que as definições de quilombos, portanto, "nos remetem à cultura, identidade, territórios, propriedades, bens econômicos, sociais, culturais e políticos. Habitação, saúde e educação das comunidades de quilombos são mutáveis em função das produções conceituais". E, legalmente, os quilombos, assim como Muquém e outros, passaram a ter como garantia dos povos que vivem em territórios quilombolas, seus direitos postos na Constituição Federal de 1988, no artigo 68, como remanescentes das comunidades dos quilombos que estejam ocupando suas terras ficando-Ihe "reconhecida a propriedade definitiva, devendo o Estado emitir-lhes os títulos respectivos". Posteriormente, no artigo 216 da CF 88, quando constituem as comunidades quilombolas como "patrimônio cultural brasileiro, os bens de natureza material e imaterial, tomados individualmente ou em conjunto, portadores de referência à identidade, à ação, à memória dos diferentes grupos formadores da sociedade brasileira". No entanto,

[...] quilombo não significa refúgio de escravizados. Trata-se de uma reunião fraterna e livre, com laços de solidariedade e convivência resultante do esforço dos negros escravizados de resgatar sua liberdade e dignidade por meio da fuga do cativeiro e da organização de uma sociedade livre. Os quilombolas eram homens e mulheres que se recusavam viver sob o regime de escravidão e desenvolviam ações de rebeldia e de luta contra esse sistema (MUNANGA; GOMES, 2007, p. 33). 
Analogamente e como marca dessa identidade, ancestralidade, resistência, de um povo que luta em busca de melhorias, o artesanato tem sido o marco histórico na vida do povo de Muquém, pois carrega herança de seus ancestrais que se mantêm vivos até os dias atuais por um grupo de idosos/as da comunidade que se debruçam diariamente a confeccionar suas obras de arte feitas à mão, com argila, como herança cultural de um povo que não se negou a lutar por sua gente em Palmares. Em Muquém, as identidades culturais têm sido construídas a partir das diferentes obras de arte que são construídas pelos diferentes artesãos. Cada um trabalha especificamente com elementos dos quais se identificam. A exemplo, Dona Irineia, esculpe obras de arte (cabeças de boneco), Dona Marinalva (com panelas, potes), Seu Edinho (com tigelas, panelas, obras de Zumbi), entre outros. Porém, ressalta-se que a identidade construída por cada um deles contribui para uma valorização do lugar onde moram, além da diversidade desses elementos culturais construídos por cada um deles.

Para tanto, a identidade "é definida historicamente e não biologicamente". Uma vez que os artesãos herdaram de seus pais, avós, o trabalho com argila, é possível compreender o quanto cada um carrega consigo o contexto histórico de como começaram a trabalhar com ela. Uma herança que cada um carrega com muito orgulho e espera que seus filhos, netos e bisnetos possam herdar esse aparelho cultural dos povos de Muquém, o artesanato com argila. Apesar que vale salientar que "o sujeito assume identidades diferentes em diferentes momentos, identidades que não são unificadas ao redor de um eu coerente" (HALL, 2006, p. 13).

A arte com panelas, esculturas e obras de arte, retratada na obra " $A$ presença negra em Alagoas" de Tenório (2015), especificamente nos textos de Costa (2015), feito com o barro, são heranças culturais dos povos africanos que viveram em Palmares. Manter essa herança viva, mesmo que escassa, pouco valorizada e invisibilizada, pessoalmente e profissionalmente é símbolo de resistência e de ocupar 
um papel de destaque no cenário nacional e consequentemente alagoano, como uma forma de lutar pela sobrevivência pessoal e coletiva do nosso povo, afirmando que eles estão aqui para falar e retratar o lugar que vivem, sua gente, seus ancestrais e não permitir que elas caiam no esquecimento. Muquém é símbolo de um povo bravo, forte e valente.

Historicamente, correlacionar Muquém com heranças dos seus povos é uma forma de manter vivos nossos ancestrais. Suas crenças, costumes, tradições sociais, culturais, religiosas, econômicas, é ocupar um lugar de resistência, em um cenário que exclui, menospreza, desqualifica social e culturalmente, também a marca da ancestralidade que há em nós. Há uma tentativa histórica em negar o povo negro e sua gente. Muquém, por ser uma, entre várias outras comunidades de remanescentes quilombolas que há no país, sofre com essa negação, quer seja de direitos básicos à saúde, educação, lazer, moradia, ou aos aspectos socioeconômicos e culturais.

Muquém é teoricamente espaço de luta e resistência do povo negro que viveu em Palmares. É o retrato de um povo que lutou décadas por reconhecimento territorial, por pertencimento cultural, social, econômico e educacional. Luta por igualdade de direito, equidade, reconhecimento e pela não negação da identidade étnica do seu povo. Uma gente séria, serena. Uma Comunidade tranquila, de um povo humilde, esperançoso em dias melhores, do campo, da roça, da luta, do trabalho artesanal, braçal.

E, a partir desses espaços, "não formais de educação", mas de representatividade para este e outros povos, temos nos perguntado, de maneira reflexiva: em que esses espaços têm contribuído para construção de uma identidade étnica das crianças e negras desses espaços? Como, para além do mito da democracia racial, da negação do seu povo, da subalternização, esses espaços têm fortalecido as relações interpessoais com o seu povo? Como as crianças e negras são representadas 
dentro do ambiente escolar? E na comunidade? Quais ações fortalecem as identidades étnicas dentro desses espaços não formais e formais de educação? Longe de nós, trazermos aqui, qualquer pré-julgamento acerca daquilo que investigaremos mais de perto em uma pesquisa vindoura. Porém, salientamos a necessidade de refletirmos sempre, acerca do que nos pertence, do que somos.

\section{A Identidade Étnico-racial das crianças e negras quilombolas: um processo de constante (re)construção}

Para refletirmos...

É janeiro de dois mil e dezoito, eis que $P \operatorname{lro}^{6}$ ministra uma palestra para jovens de uma comunidade rural, de uma escola da rede pública, acerca da proteção ambiental, dos animais, dos riscos e danos causados se não cuidarmos dele, do meio ambiente, e José trava o seguinte diálogo com o palestrante:

- José: Pedro, veja bem.

- Pedro: pois não?

- José: se por ventura eu manter em cativeiro algum macaco em casa, preso, o que é possível de acontecer comigo?

- Pedro: no mínimo, você precisa liberar o animal, o bicho, o macaco, porque é crime manter qualquer animal em cativeiro e você poderá ir preso, responder processo judicialmente.

José olha para João, um adolescente e negro, bate no ombro dele e diz:

- José: ah! João, então eu vou ter que te soltar velho...

Se essas situações cotidianas te incomodam, como a nós incomoda, significa no mínimo dizer, que precisamos dialogar diariamente sobre os "silenciamentos", "rasgões de pele", "invisibilidades", discriminações, racismo, preconceito, a qual as

\footnotetext{
${ }^{6}$ Os nomes dos sujeitos são fictícios em razão de preservar suas verdadeiras identidades.
} 
crianças e negras sofrem dentro e fora do ambiente escolar, também. Precisamos pensar várias maneiras, não como uma fórmula pronta, acabada, com reais possibilidades de reforçarmos nossas identidades étnicas, nossa cor de pele, dentro e fora desses ambientes formais que contribuem direta e indiretamente para a nossa formação identitária étnica.

Inclusive, convidamos você para conosco repensar nossas práticas diárias, no que temos feito para amenizar as mazelas do preconceito em nossos espaços. Como temos ressignificado nossos discursos diante dessa barbárie que ainda nos menospreza, nos corta a pele sem sangrar? Ou será que temos apenas intervindo com palavras de ordem, do tipo: "menino, não fale isso, isso é preconceito"; "menina, olhe o respeito pelo coleguinha"; "meninos, não chamem disso o coleguinha, isso é feio, você sabia?".

Respeitamos toda e qualquer prática, discurso, mas precisamos salientar que é necessário romper com esses discursos que em nada contribuem para nossa formação identitária e atrelarmos aos nossos projetos políticos pedagógicos, aos nossos planos de aulas, aos nossos planejamentos, ações políticas pedagógicas, que nos ensinem a refletir sobre a construção de um país desigual, sobre quem era tratado como coisa e como pessoa, sobre nossa ancestralidade, sobre o combate ao racismo, ao preconceito e à discriminação racial, sobre as histórias da África, sobre as religiões de matriz africana, acima de tudo, sobre uma educação antirracista. Que rompa com o eurocentrismo que teima em nos perseguir, curricularmente falando, até os nossos dias atuais.

Aponta-se que os caminhos aqui trilhados perpassarão também sob a condição de dois pesquisadores e negros, que assim como tantas outras crianças e negras, sofreram preconceito por serem negros/as e que a cada instante, nossos coleguinhas de sala nos atribuíam os mais enojados apelidos pejorativos: "negrinho", "carvão", 
"tição", "nego fedorento", "urubu", "sola de sapato", "ave de coqueiro" e tantos outros. Esses estereótipos reforçam a ideia de que as crianças negras geralmente são apresentadas como os filhos das empregadas, não lhes são atribuídos nomes, mas apelidos por sua cor de pele, além de perceber ausência de características e atributos de gente e os associam a animais (SILVA, 2004).

Não distante do que destaca a autora e sentir isto na pele, serem comparados em vários momentos da infância a seres sobrenaturais, animais, coisas "inúteis", nos subiam uma sensação de impotência, revolta, dor, ódio, medo, solidão. E o pior: o silenciamento. Esse acarreta uma omissão também por parte dos colegas que presenciavam e não sabiam como reagir, a não ser, rir; dos professores, que na verdade, eram o que mais nos incomodavam, e os tornavam indiretamente cúmplices; dos gestores, por não saber lidar com as devidas situações, por não elaborarem propostas pedagógicas que fossem capazes de fortalecer as relações étnicas no ambiente escolar. E é importante ressaltar que a despreocupação com as convivências multiétnicas quer na família, quer na escola, pode colaborar para a formação de indivíduos preconceituosos e discriminadores (CAVALLEIRO, 2000).

Contemporaneamente, precisamos nos atentar para uma escola que supere todas as formas de preconceito e discriminação existentes no seu entorno. Gomes (2010, p. 104) aponta que

\footnotetext{
A escola brasileira, pública e particular, está desafiada a realizar uma revisão de posturas, valores, conhecimentos, currículos na perspectiva da diversidade étnico-racial. Nos dias atuais, a superação da situação de subalternização dos saberes produzidos pela comunidade negra, a presença dos estereótipos raciais nos manuais didáticos, a estigmatização do negro, os apelidos pejorativos e a versão pedagógica do mito da democracia racial (igualdade que apaga as diferenças) precisam e devem ser superados no ambiente escolar não somente devido ao fato de serem parte do compromisso social e pedagógico da escola no combate ao racismo e à discriminação racial, mas, também, por força da lei.
} 
Obviamente que temos encontrado um currículo escolar único, no qual há uma valorização de culturas e povos europeus e em vasto momento uma inferiorização dos estudos, ensino da cultura, história da África e dos afro-brasileiros nos currículos escolares. É desafiador inserir e romper com a lógica que está posta nos currículos e, para isto é necessário, como salientado por Silva (2005), uma prática pedagógica que possa ver e consertar os estereótipos negativos e a invisibilidade pela qual as crianças negras são apresentadas, como, por exemplo, nos livros didáticos.

Se pensarmos sobre a representatividade das crianças negras nos livros didáticos, na literaturas infanto-juvenil, é fácil perceber o quanto elas têm sido negadas, o quanto suas autoestimas são baixas. $E$, se analisarmos como essa criança negra tem sido apresentada, compartilhamos do pensamento de Abramowicz e Gomes (2010), em que as pesquisas apontam-nas, a partir de um modelo, de um ser em desenvolvimento, de baixa estima, em que o ensino não capta para si as suas diferenças, diversidades pessoais, culturais, e ainda se baseia em um único modelo de cultura e indivíduo para negar a do outro.

Abramowicz e Gomes (2010) ressalta que a cultura negra é negada na escola e, consequentemente, no currículo. E ainda, segundo ela, essa negação não está atrelada apenas ao modo de inexistência, silêncio, omissão, mas também como uma forma de não enxergar, de quebrar um 'pacto' que não possa se quebrar; do contrário, teríamos que refazer o currículo e a escola. Necessitamos de um currículo escolar que além de educar as crianças para uma boa convivência multiétnica, realize estudos, promova formações continuadas que contemplem as diversidades de raça/cor, gênero/sexualidade, credo/religião.

Para além, que faça uso dos documentos legais que orientam e norteiam para educação das relações étnico-raciais, a exemplo: as leis federais, 10.639/03; 11.645/08; a resolução de № 01/2004 de 17 de junho de 2004 do Conselho Nacional 
de Educação que institui as Diretrizes Curriculares Nacionais para a Educação das Relações Étnico-raciais e para o Ensino de História e Cultura Afro-Brasileira e Africana que resulta no parecer de № 04/2004, aprovado 10 em julho do mesmo ano (BRASIL, 2004); as Diretrizes Curriculares para Educação Escolar Quilombola na Educação Básica (BRASIL, 2008). A partir deles, é possível repensar o currículo e propor uma quebra dessa hegemonia e começar a repensar outras práticas pedagógicas que possam fortalecer a identidade étnica das crianças e negras.

Nesse cenário educacional se encontram as crianças negras e não negras, que terão a escola como uma das primeiras instituições na qual o processo de socialização acontecerá posteriormente à familiar, além da igreja e da vizinhança. Durante esse processo de socialização, será comum as crianças encontrarem algumas adversidades, afinal, a escola é espaço de adversidade, desde que esta não negue e prejulgue a existência do outro. É importante destacar que

O processo de socialização pensado e construído como uma maneira asséptica e indolor de produzir crianças e configurar infâncias é um processo nem simples, nem fácil e nem mesmo indolor. A socialização é um processo social de exercício de poder e saber que se impõem sobre a criança, para produzi-las. A partir dos pressupostos da Sociologia, este processo deve ser entendido e descrito com a participação ativa da criança: ora resistindo, ora reinventando, ora imitando, ora aceitando etc. (ABRAMOWICZ; OLIVEIRA, 2010, p. 42).

A infância de muitas crianças e negras, a partir das crianças que fomos - e que possivelmente você também - vivenciamos e presenciamos, não tem sido em muitas situações o lugar de tranquilidade, passividade, de boas relações multiétnicas. Constantemente passam por situações que tentam inferiorizá-las, prejulgá-las, menosprezá-las e até mesmo subalternizá-las. Esse não é o lugar da infância, da criança e negra porque a socialização perpassa pelo caminho da autonomia, segurança, respeito. É o lugar da autonomia que as crianças possuem, dos múltiplos significados 
que suas falas nos dizem. É o lugar do sentir, agir, pegar, tocar, rir, se emocionar, se conhecer, conhecer o outro, se pertencer e, ser quem é, se reconhecer no que se é.

Se não é esse, então, o lugar da criança na pesquisa, de que lugar, de que criança pretendemos discorrer aqui? Inicialmente, o lugar, por se tratar de uma comunidade de remanescentes quilombolas, pode ser visto por muitos ignorantes como um local de negros que foram escravizados no período colonial e fugiram das senzalas, que após a derrubada de Palmares formaram-se tais comunidades. Mas estamos além de ser apenas uma comunidade de descendentes de escravizados, porque deles carregamos nossas crenças, costumes e tradições.

Para além, a partir da Sociologia da Infância, pensamos em uma criança, que mesmo considerando a homogeneidade em um determinado grupo por faixa etária, é preciso considerar os fatores heterogêneos como classe social, gênero, etnia, raça, religião etc., levando em consideração que há diversos fatores culturais e estruturais que diferenciam as crianças (ABRAMOWICZ; OLIVEIRA, 2010). Nessa perspectiva, estudos como o de Cohn (2005, p. 35 apud, SANTOS; ANJOS; FARIA, 2017, p. 167) têm mostrado que

\begin{abstract}
As crianças não são apenas produzidas pelas culturas, mas também produtoras de cultura. Elas elaboram sentidos para o mundo e suas experiências compartilhando plenamente de uma cultura. Esses sentidos têm uma particularidade, e não se confundem e nem podem ser reduzidos àqueles elaborados pelos adultos; as crianças têm autonomia cultural em relação ao adulto. Essa autonomia deve ser reconhecida, mas também relativizada: digamos, portanto que elas têm uma relativa autonomia cultural. Os sentidos que elaboram partem de um sistema simbólico compartilhado com os adultos. Negá-lo seria ir de um extremo ao outro; seria afirmar a particularidade da experiência infantil sob custo de cunhar uma nova, e dessa vez, irredutível, cisão entre os mundos, seria tornar esses mundos incomunicáveis.
\end{abstract}

E a criança negra e quilombola, filha de homens e mulheres do campo, que carregam nas suas raízes genealógicas as marcas de seus ancestrais e saberes culturais 
produzidos por eles, encontra-se nessa produção de saberes culturais, pelos mais variados contextos sociais que está inserida, que transita pela família, pela vizinhança, na escola, entre outros. Ressalta-se a importância de as crianças e negras aprenderem a produzir seus elementos culturais, próprios do seu povo, de seu pertencimento étnico.

Conceber as crianças como sujeitos é estar em consonância com o princípio de que elas são capazes, competentes, que possuem um universo de conhecimentos e de formas de expressões a serem conhecidos pelos adultos. Porém, para se conhecer as possibilidades infantis, é necessário ouvir e, por conseguinte, refinar formas de escuta das crianças, atividade que ainda é pouco explorada nas pesquisas (SANTOS; ANJOS; FARIA, 2017). Uma vez que elas falam por gestos e expressões, precisamos estar atentos para esses olhares com as crianças e negras, pois em muitas situações são vítimas de um produto cultural eurocêntrico.

Assim, para Santos, Anjos e Faria (2017, p. 168), “o movimento, a brincadeira, o desenho, a fala, a escrita, dentre outros, são recursos da expressão da criança". E, "buscar formas de ouvir as crianças, explorando as suas múltiplas linguagens, tem como pressupostos a crença de que elas têm o que dizer e o desejo de conhecer o ponto de vista delas" (CRUZ, 2008, p. 13). Destacam-se ainda as suas contribuições para a pesquisa, pois, ouvi-las agrega as diferentes possibilidades de olhares, gostos, desejos, sensações, limitações, inibições, além das expressões causadas por situações correlatas de preconceito e discriminação por conta da cor da pele, bem como pela ausência da comunicação em denunciar tais atos.

Nessa direção, Abromowicz e Rodrigues (2014, p. 462) nos direcionam para uma descolonização que para elas é

produzir uma processualidade na qual é possível constituir experiências sociais e individuais singulares, que descentralizem, ou façam fugir os modelos e lugares hegemônicos que centralizam sentidos, norma, estética, 
saúde, entre outros; dominantes e que se constituam para além da lógica do capital.

E, romper com essa lógica do capital, especificamente a educacional, é romper com práticas racistas, nas quais crianças e negras levam empurrões, são xingadas, são chamadas de "bonecas de piche", "cabelo de bombril", de "fuar", "nega do cabelo duro" entre tantos outros. Precisamos romper com essas práticas dentro do ambiente escolar e, consequentemente, em uma escola localizada em comunidades de remanescentes quilombolas é tarefa desafiadora de todos que compõem o ambiente escolar. No currículo da Educação Escolar Quilombola, tal como está posto nas Diretrizes, devem os

modos de organização dos tempos e espaços escolares de suas atividades pedagógicas, das interações do ambiente educacional com a sociedade, das relações de poder presentes no fazer educativo e nas formas de conceber e construir conhecimentos escolares, constituindo parte importante dos processos sociopolíticos e culturais de construção de identidades (BRASIL, 2008, p. 13).

Do jeito que está posto no documento que direciona os meios para a educação nesse espaço escolar, nos cabe indagar: como estão organizados os tempos escolares, as atividades pedagógicas na escola de Muquém contemplam a identidade étnica da criança e negra? Permite um intercâmbio entre ambiente escolar e a comunidade local? Os saberes construídos dentro da escola levam em consideração os trazidos pelos educandos e fortalecem seus processos sociais, culturais e auxiliam na construção de suas identidades? São questionamentos a fazer acerca do currículo da escola quilombola que, se bem trabalhados, poderão ajudar no fortalecimento das identidades e de suas representações.

Para Silva (2015), um currículo que se preocupe com a questão do racismo deveria colocar no centro de suas práticas pedagógicas a noção de representação tal 
como definidas pelos estudos culturais. Isso permite deslocar a ênfase de uma preocupação realista com a verdade para uma preocupação política com as formas pelas quais a identidade é construída por meio da representação. $E$, construir a identidade das crianças e negras de forma positiva proporcionará formá-las cada vez mais cientes do papel que assumem nos espaços, no lugar, na sociedade em que elas estão inseridas.

Silva (2014) aponta que a

afirmação da identidade e a marcação da diferença implicam, sempre, as operações de incluir e de excluir. Como vimos, dizer "o que somos" significa também dizer "o que não somos". A identidade e a diferença se traduzem, assim, em declarações sobre quem pertence e sobre quem não pertence, sobre quem está incluído e quem está excluído.

A partir dessa perspectiva, muitas vezes perguntamos a uma criança branca de que cor ela é, certamente ela responderá branca, afirmando sua cor. Mas, em algum momento, se perguntamos a muitas crianças e negras de que cor elas são, não precisamente, mas em sua maioria, poderá dar várias respostas para dizer que não é negra.

O que estamos querendo na verdade, de acordo com Candau (2007), é dar outra conotação, negar a padronização e lutar contra as formas de desigualdade presentes na sociedade e no ambiente escolar. Nem padronizar, nem igualar, mas lutar pela igualdade e pelo reconhecimento das diferenças de modo que possamos promover os direitos básicos de todas as pessoas, queremos que as diferenças sejam reconhecidas como elementos de construção da igualdade.

\section{Inconclusões}

Este trabalho teve como objetivo analisar as referências bibliográficas sobre a construção da autoestima e afirmação das identidades negras nas crianças 
quilombolas. A motivação se deu após a nossa entrada numa escola quilombola localizada na Comunidade Quilombola do Muquém - AL, e observarmos que as crianças negras possuíam narrativas negativas quanto às representações simbólicas e imaginárias negras.

Verificamos que o artesanato tem sido o marco histórico na vida do povo de Muquém, pois carrega herança de seus ancestrais que se mantêm vivos até os dias atuais por um grupo de idosos/as da comunidade que se debruçam diariamente a confeccionar suas obras de arte feitas à mão, com argila, como herança cultural de um povo que não se negou a lutar por sua gente em Palmares. Manter essa herança viva é símbolo de resistência e de ocupar um papel de destaque no cenário nacional e consequentemente alagoano, como uma forma de lutar pela sobrevivência pessoal e coletiva do povo, afirmando que eles estão lá para falar e retratar o lugar que vivem, sua gente, seus ancestrais e não permitir que essas caiam no esquecimento.

Muquém, por ser uma, entre várias outras comunidades de remanescentes quilombolas que há no país, sofre para a preservação de seus direitos básicos à saúde, educação, lazer, moradia, ou aos aspectos socioeconômicos e culturais. E, a partir desses espaços, refletimos sobre como os espaços educativos dessas comunidades têm contribuído para construção de uma identidade étnica das crianças e negras.

Consideramos que a superação da situação de subalternização dos saberes produzidos pela comunidade negra, a presença dos estereótipos raciais nos manuais didáticos, a estigmatização do negro, os apelidos pejorativos e a versão pedagógica do mito da democracia racial precisam e devem ser superados no ambiente escolar não somente devido ao fato de serem parte do compromisso social e pedagógico da escola no combate ao racismo e à discriminação racial, mas, também, por força da lei. Obviamente que encontramos um currículo escolar único, no qual há uma valorização de culturas e povos europeus e em vasta inferiorização dos estudos, ensino da cultura, 
história da África e dos afro-brasileiros nos currículos escolares.

É desafiador inserir e romper com a lógica que está posta nos currículos e, para isto é necessária uma prática pedagógica que possa admitir e eliminar os estereótipos negativos e a invisibilidade que as crianças negras têm, como por exemplo, nos livros didáticos. As representatividades das crianças negras nos livros didáticos, nas literaturas infanto-juvenis têm sido negadas. E, ao analisarmos como essa criança negra tem sido apresentada nas pesquisas, observamos que modelo ideal é a criança branca e o ensino não capta para si as diferenças, as diversidades pessoais, culturais. Cabe lembrar que a resolução de no 01/2004 de 17 de junho de 2004, do Conselho Nacional de Educação que institui as Diretrizes Curriculares Nacionais para a Educação das Relações Étnico-raciais e para o Ensino de História e Cultura Afro-Brasileira e Africana, que resultou no parecer de № 04/2004, aprovado 10 em julho do mesmo ano, repensou o currículo e propôs uma quebra dessa hegemonia e orientou a repensar, a partir deles, outras práticas pedagógicas que possam fortalecer a identidade étnica das crianças e negras.

Nesse cenário educacional encontram-se as crianças negras e não negras, que terão na escola uma das primeiras instituições na qual o processo de socialização acontecerá posteriormente a familiar, além da igreja e da vizinhança. Os estudos apresentados ao longo deste trabalho, ao tratarem de comunidades de remanescentes quilombolas, têm de forma subjacente a ideia de que elas são ignorantes, e as comunidades quilombolas são vistas como um local de negros que foram escravizados no período colonial e fugiram das senzalas e que após a derrubada de Palmares formaram tais comunidades.

Ao não encontrarmos estudos que pesquisaram relações étnico-raciais em interface com educação quilombolas, apontamos a necessidade de pensarmos em uma criança que mesmo considerando a homogeneidade em um determinado grupo por 
faixa etária precisa considerar os fatores heterogêneos como classe social, gênero, etnia, raça, religião etc., levando em consideração que há diversos fatores culturais e estruturais que a diferencia. Compreendemos que é fundamental afirmar a particularidade da experiência infantil sob custo de cunhar uma nova com uma cisão entre os mundos. A criança negra e quilombola, que carrega nas suas raízes genealógicas as marcas de seus ancestrais e saberes culturais produzidos por eles, encontra-se invisibilizada nesta produção de saberes culturais, pelos mais variados contextos sociais que está inserida, que transita pela família, pela vizinhança, na escola, entre outros.

Destacamos que ouvir essas crianças agregaria diferentes possibilidades de olhares, gostos, desejos, sensações, limitações, inibições, além das expressões causadas por situações correlatas de preconceito e discriminação por conta da cor da pele, bem como pela ausência da comunicação em denunciar tais atos. E, construir a identidade das crianças e negras de forma positiva proporcionará formá-las cada vez mais cientes do papel que assumem nos espaços, no lugar, na sociedade em que elas estão inseridas.

O que estamos idealizando é dar outra conotação, negar a padronização e lutar contra as formas de desigualdade presentes na sociedade e no ambiente escolar. Nós necessitamos, nesse sentido, de estudos que apontem a igualdade e o reconhecimento das diferenças de modo que possamos promover os direitos básicos de todas as pessoas, e que essas diferenças sejam reconhecidas como elementos de construção da igualdade, especialmente da identidade da criança negra quilombola.

\section{Referências}

ABRAMOWIZ, A.; GOMES, N. L. Educação e raça: perspectivas políticas, pedagógicas e estéticas. Belo Horizonte: Autêntica, 2010. 
ABRAMOWIZ, A.; OLIVEIRA, F. A Sociologia da infância no Brasil: uma área em construção. Educação, Santa Maria, v. 35, n. 1, p. 39-52, jan./abr. 2010. Disponível em: https://periodicos.ufsm.br/reveducacao/article/view/1602. Acesso em: 25 jan. 2016.

ABRAMOWIZ, A.; RODRIGUES, T. C. Descolonizando as pesquisas com crianças e três obstáculos. Educação \& Sociedade, Campinas, v. 35, n. 127, p. 461-474, abr./jun. 2014. Disponível em: http://www.scielo.br/pdf/es/v35n127/v35n127a07.pdf. Acesso em: 25 jan. 2016.

ARAÚJO, Z. Dona Marinalva - saberes e fazeres. In: TENÓRIO, D. A. et al. A presença negra em Alagoas. Brasília. Senado Federal, Conselho Editorial, 2015.

ARRUTI, J. M. Mocambo: antropologia e história do processo de formação quilombola. São Paulo: EDUSC, 2005.

BRAGA JR., A; SILVA, J. G. Breve panorama sobre o cumprimento da Lei 10.639/03 em Maceió/AL. Identidade, São Leopoldo, v. 18, n. 1, p. 112-121, jan./jun, 2013.

Disponível em:

http://periodicos.est.edu.br/index.php/identidade/article/viewFile/476/686. Acesso em: 25 jan. 2016.

BRASIL. Lei no 11.645, de 10 de março de 2008. Altera a Lei $n=9.394$, de 20 de dezembro de 1996, que estabelece as diretrizes e bases da educação nacional, para incluir no currículo oficial da rede de ensino a obrigatoriedade da temática "História e Cultura Afro-Brasileira e Indígena". Brasília, DF: mar. 2008. Disponível em:

http://www.planalto.gov.br/ccivil_03/_Ato2007-2010/2008/Lei/L11645.htm. Acesso em: 18 fev. 2019.

BRASIL. Parecer CP/CNE 03/2004. Diretrizes Curriculares Nacionais para a Educação das Relações Étnico-Raciais e para o Ensino de História e Cultura Afro-Brasileira e Africana. Brasília, DF: 2004. Disponível em:

http://portal.inep.gov.br/documents/186968/484184/Diretrizes+curriculares+nacion al+para+a+educa\%C3\%A7\%C3\%A3o+das+rela\%C3\%A7\%C3\%B5es+\%C3\%A9tnicoraciais+e+para+o+ensino+de+hist\%C3\%B3ria+e+cultura+afrobrasileira+e+africana/f66ce7ca-e0c8-4dbd-8df3-4c2783f06386?version=1.2. Acesso em: 18 fev. 2019.

BRASIL. Lei no 10.639 de 9 de janeiro de 2003. Altera a Lei no 9.394, de 20 de dezembro de 1996, que estabelece as diretrizes e bases da educação nacional. Brasília, 2003. Disponível em: http://www.planalto.gov.br/ccivil_03/leis/2003//10.639.htm. Acesso em: 18 fev. 2019. 
BRASIL. Lei no 11.645 de 10 de março de 2008. Altera a Lei no 9.394, de 20 de dezembro de 1996, que estabelece as diretrizes e bases da educação nacional. Brasília, 2008. Disponível em: http://www.planalto.gov.br/ccivil_03/_Ato20072010/2008/Lei/L11645.htm. Acesso em: 18 fev. 2019.

BRASIL. Ministério da Educação. Secretaria da Educação Continuada, Alfabetização e Diversidade. Orientações e Ações para Educação das Relações Étnico-Raciais. Brasília, 2006. Disponível em: http://portal.mec.gov.br/dmdocuments/orientacoes_etnicoraciais.pdf. Acesso em: 18 fev. 2019.

BRASIL. Parecer CNE/CP no. 003, de 10 de março de 2004b. Diretrizes Curriculares Nacionais para Educação das Relações Étnico-Raciais e para o Ensino de História e Cultura Afro-Brasileira e Africana. Disponível em: http://portal.mec.gov.br/dmdocuments/cnecp_003.pdf. Acesso em: 18 fev. 2019.

BRASIL. Resolução no 1, de 17 de junho de 2004a. Institui as Diretrizes Curriculares Nacionais para a Educação das Relações Étnico-Raciais e para o Ensino de História e Cultura Afro-Brasileira e Africana. Parecer CP/CNE 03/2004a. Brasília, 22/06/2004. Disponível em: http://portal.inep.gov.br/informacao-da-publicacao//asset_publisher/6JYIsGMAMkW1/document/id/488171. Acesso em: 18 fev. 2019. CANDAU, V. S. Educação em direitos humanos: desafios atuais. In: SILVEIRA, R. M. G. et al. Educação em direitos humanos: fundamentos teórico-metodológicos. João Pessoa: Editora Universitária, 2007. p. 399-412.

CAVALLEIRO, E. Do silêncio do lar ao silêncio escolar: racismo, preconceito e discriminação na educação infantil. São Paulo: Contexto, 2000.

COSTA, J. J. C. Irineia e as suas figuras enigmáticas: um mapeamento histórico e iconográfico. In: TENORIO, D. A. (org.). A presença negra em alagoas. 2. ed. Brasília DF: Editora do Senado, 2015.

CRUZ, S. H. V. A criança fala: a escuta de crianças em pesquisas. São Paulo: Cortez, 2008.

CUNHA JUNIOR, H. Quilombo: patrimônio histórico e cultural. Revista espaço acadêmico, ano XI, n. 129, 2012.

FIABANI, A. Mato, palhoça e pilão: o quilombo, da escravidão às comunidades remanescentes (1532 - 2004). 2 ed. São Paulo: Expressões Popular, 2012.

FREYRE, G. Casa-Grande \& Senzala. 51. ed. São Paulo: Global Editora, 2006.

FUNARI, P. P. A. A arqueologia de Palmares: sua contribuição para o conhecimento da 
história da cultura afro-americana. In: REIS, J. J.; GOMES, F. S. Liberdade por um fio: história dos quilombos no Brasil. São Paulo: Claro Enigma, 2012. p. 29-57.

GENNARI, E. Em busca da liberdade: traços das lutas escravas no Brasil. 2. ed. São Paulo: Expressão popular, 2011.

GOMES, N. L. (org.). Um olhar além das fronteiras: educação e relações raciais. Belo Horizonte: Autêntica, 2010.

GUIMARÃES, G. A cor da ternura. 12. ed. São Paulo: FTD, 1998.

HALL, S. A identidade cultural na pós-modernidade. Tradução: Tomaz Tadeu Silva, Guaracira Lopes Louro. 11. ed. Rio de Janeiro: DP\&A, 2006.

MINAYO, M. C. S. Pesquisa social: teoria, método e criatividade. Petrópolis: Vozes, 2016.

MUNANGA, K.; GOMES N. L. O negro no Brasil de hoje. São Paulo: Global, 2007. (Coleção para entender).

NASCIMENTO, A. O quilombismo. Petrópolis: Vozes. 1980. Disponível em: https://baobavoador.noblogs.org/files/2016/01/o-quilombismo-abdias-donascimento.pdf. Acesso em: 23 jul. 2017.

SANTOS, S. E.; ANJOS, C. I.; FARIA, A. L. G. A criança das pesquisas, a criança nas pesquisas... a criança faz pesquisa? Práxis Educacional (online), v. 13, p. 158-175, 2017.

SANTOS, S. E.; ANJOS, C. I.; FARIA, A. L. G. A criança das pesquisas, a criança nas pesquisas... a criança faz pesquisa? In: Práxis Educacional, Vitória da Conquista: Universidade Estadual do Sudoeste da Bahia, v. 13, n. 25, p. 158-175, abril de 2017. Disponível em: http://periodicos2.uesb.br/index.php/praxis/article/view/958. Acesso em: 20 nov. 2019.

SCHIMDT, A.; TURATTI, M. C. M.; CARVALHO, M. C. P. A atualização do conceito de quilombo - identidade e território nas definições teóricas. Ambiente e Sociedade (Campinas), ano V, p. 45-48, 2002.

SCHWARCZ, L. M. Nem preto nem branco, muito pelo contrário: cor e raça na sociedade brasileira. São Paulo: Claro Enigma, 2012.

SILVA, A. C. A. A representação social do negro no livro didático: o que mudou? por que mudou? Salvador: EDUFBA, 2011.

SILVA, A. C. A. A discriminação do negro no livro didático. 2. ed. Salvador: EDFUBA, 2004.

SILVA, A. C. A. Desconstrução da Discriminação no Livro Didático. In: MUNANGA, K. 
Superando o Racismo na escola. 2. ed. revisada. [Brasília]: Ministério da Educação, Secretaria de Educação Continuada, Alfabetização e Diversidade, 2005.

SILVA, T. T. A produção social da identidade e da diferença. In: SILVA, T. T.; HALL, S.; WOODWARD, K. Identidade e diferença: a perspectiva dos estudos culturais. 15. ed. Petrópolis: Vozes, 2014. p. 73-112.

SILVA, T. T. Documentos de identidade: uma introdução as teorias críticas do currículo. 3. ed. 7. reimp. Belo Horizonte: Autêntica, 2015.

TENORIO, D. A. (org.). A presença negra em alagoas. 2. ed. DF: Editora do Senado, 2015.

Enviado em: 29/05/2019

Aprovado em: 28/12/2019 